\title{
Benchmarking and Rating of Private Commercial Banks of Bangladesh Through CAMELS Components
}

\author{
A H M Ziaul Haq $P h D$ \\ Professor \\ Department of Finance \\ University of Rajshahi, Bangladesh \\ E-mail: zia_haq200I@yahoo.com \\ Hosnay Nasrin \\ $\mathrm{PhD}$ Fellow \\ Department of Finance \\ University of Rajshahi, Bangladesh \\ E-mail: hn_nahin@yahoo.com
}

Received: August 30, 2020

Accepted: September 13, 2020

Online Published: September 27, 2020

doi: I0.4628I/bjmsr.v2i2.783

URL: https://doi.org/I0.4628I/bjmsr.v2i2.783

\begin{abstract}
The banking sector of Bangladesh is becoming more complicated than before. Ensuring the financial stability of the economy, monitoring, supervision, and continuous performance evaluation of the banking sector are compulsory. The present study, therefore, is an attempt to evaluate and compare the performance of our banks. One of the most effective supervisory techniques, CAMELS rating system has been used to benchmark and rate the banks based on their performance. In this study, 2I private commercial banks (PCBs) have been chosen as samples to meet the purpose of the study. Data for analysis has been collected from the banks' annual reports for the period of 2008 to 2018. The result shows that none of the banks could achieve a 'strong' position, and only SEBL was able to secure a 'satisfactory' mark. Unfortunately, AB bank was rated "marginal" in the composite rating, which is the lowest rating among the sample banks. Hence, $\mathrm{AB}$ bank needs to develop reform and follow-up programs as soon as possible to avoid financial failure.
\end{abstract}

\section{Keywords: Private Commercial Banks, Performance Evaluation, CAMELS Components, Benchmarking, Composite Rating.}

\section{Introduction}

Since the banking industry has become globalized and liberalized, so clients everywhere in the world would quickly look forward to the identical world-class support from any bank offering a similar service, as customers always expect better service; therefore, benchmarking is a competitive strategy to win over the market shares, and a survival approach for threatened businesses and industries. Initially, banks should conduct benchmarking with their competitors or banks having excellent performance in the banking industry operating anywhere in the world. Secondly, banks can benchmark with their affiliates, sister companies, and subsidiaries which may be performing specific practices a lot better than the bank does. Finally, banks can also benchmark their performance with companies outside the industry whose approaches can be tailored to the banks themselves. After benchmarking, banks can realize their rating of performance in specific key areas. CAMELS is used as a benchmarking tool to evaluate the performance of commercial banks.

Benchmarking is a process of comparing the performance of one business with its rivals. (Tzu, 2002) mentioned in his study that benchmarking is the system of finding out the comparative significance of something by relating it to a recognized criterion. And (Anderson \& McAdam, 2006) stated in their study that benchmarking is used as a method of evaluating practices and choosing new strategies to sustain a company. The role of benchmarking in British banking is narrated in research by (Knights \& McCabe, 2006) in detail as well. Through benchmarking, British banks have gradually adopted quality initiatives and gained significant success in quality management, the results showed. 
The banking sector of Bangladesh is divided into four classifications of scheduled banks; State-Owned Commercial Banks (SCBs), Government Owned Development Financial Institutions (DFIs), Private Commercial Banks (PCBs), and Foreign Commercial Banks (FCBs). The number of banks in Bangladesh was increased to 59 in 2018, and the number of bank branches increased to I0286 in 2018. Table I shows the banking structure in Bangladesh. (December 20I8). In Table I, it is observed that PCBs' deposits in 2018 amounted to BDT. 7127.2 billion Or 66 percent in the total deposit and its share in the total assets also increased to 67 percent during the same period. Since PCBs are dominating the whole banking industry in terms of assets and deposits, it is, therefore, essential to evaluate the performance of PCBs whether they are running on the right track.

Table I. Banking Structure in Bangladesh (2018-in Billion Tk.)

\begin{tabular}{ccccccc}
\hline Bank Type & $\begin{array}{c}\text { Number of } \\
\text { Banks }\end{array}$ & $\begin{array}{c}\text { Number of } \\
\text { Branches }\end{array}$ & $\begin{array}{c}\text { Total } \\
\text { Assets }\end{array}$ & $\begin{array}{c}\text { \% of Industry } \\
\text { Assets }\end{array}$ & Deposits & $\begin{array}{c}\text { \% of } \\
\text { Deposits }\end{array}$ \\
\hline SCBs & 6 & 3746 & 3732.2 & 25.6 & 2868.4 & 26.6 \\
\hline DFIs & 3 & I4I2 & 324.0 & 2.2 & 286.0 & 2.6 \\
\hline PCBs & $4 \mathrm{I}$ & 5060 & 9769.7 & 67.0 & 7127.2 & 66.0 \\
\hline FCBs & 9 & 68 & 747.1 & 5.2 & 517.2 & 4.8 \\
\hline Total & 59 & I0286 & I4572.9 & I00 & I0798.7 & 100 \\
\hline
\end{tabular}

Source: Annual Report of Bangladesh Bank, 2018-19

So, the banks of Bangladesh need to conduct benchmarking, which is a modern process of comparing the performance of one business with its rivals. Hence, this study aims to conduct benchmarking of the selected PCBs to apprehend the performance of the selected banks using the CAMELS components.

\section{I.I Statement of the Problem}

Bangladesh's financial system is dominated by banks where the banking system accounts for around 96 percent of the total assets of the financial sector. As the banking sector is the leading component of the overall financial system in Bangladesh, so it is essential to ensure the soundness of its banking system for the socio-economic development of the country. It is crucial to assess and evaluate the overall performance of banks in Bangladesh through the implementation of a regulatory banking supervision framework.

Various constraints hinder the development of the banking sector including PCBs of Bangladesh which includes, among others, numerous forms of banking scams such as money laundering, non-performing loans (NPLs), etc. Some banks still have been facing capital shortfalls and fail to maintain the BASEL requirement. Because of the high focus of loans and advances, the vulnerability of assets to credit risk increases. Because of high NPLs banks experience enormous stress to earn a profit, and the financial stability of the banks becomes day by day. It has been observed that there is a negative and reverse relationship that exists between NPLs and the profitability of banks. Again, due to the growing size of NPLs, banks are now facing difficulties at maintaining healthy liquidity. According to a recent study (Raju, 2017), the cost efficiency level of 35 commercial banks of Bangladesh is 9I.4 percent. On the other hand, the earnings ability of these banks has also been decreasing alarmingly. So, this scenario reflects negatively in the overall banking industry performance of Bangladesh.

At this stage, it is essential to examine the fundamental factors which affect the performances of banks in Bangladesh. The additional focus of the study is to examine the rating of the PCBs of Bangladesh through benchmarking based on CAMELS components. Among different prevalent approaches, the CAMELS rating system is the most preferred approach used by regulators and scholars. Bangladesh Bank introduced CAMELS in I993 as an integral part of the off-site supervision system.

\section{I.2 Research Questions}

Hence, keeping the statement of the problem in mind, the ultimate goal of the study has been set to address the following questions;

- How to benchmark the performance of the PCBs of Bangladesh with respect to composite rating?

- What has been the level of the soundness of the PCBs of Bangladesh? 


\section{I.3 Objectives of the Study}

The prime objective of the study is to conduct benchmarking to evaluate the performance of the PCBs of Bangladesh from the year 2008 to 2018 . The following are the specific objectives:

- To benchmark the performance of the PCBs of Bangladesh, and

- To analyze the performance of the PCBs of Bangladesh using the CAMELS components.

\section{Literature Review}

The study reviewed various studies in the area of performance evaluation of banks, CAMELS rating, and benchmarking, which were conducted in Bangladesh and abroad. Some of the literature reviews are as follows:

The CAMELS approach measures the financial performance of banking institutions. Under this system, each banking institution is examined based on six vital magnitudes concerning the bank's operations and performance mentioned by (Sahajwala \& Van den Bergh, 2000).

(Barr, Killgo, Siems, and Zimmel (2002) states that CAMELS rating has become a concise and indispensable tool for examiners and regulators.

The rating ensures a bank's healthy conditions by reviewing different aspects of a bank based on a variety of information sources such as financial statements, funding sources, macroeconomic data, budget and cash flow (Suba, 2015) gave a comprehensive framework on the CAMELS model. The author gave detailed definitions of the ratios and the interpretations of them to form a structural model on them.

CAMEL parameters were used by (Sangmi \& Nazir, 2010) to evaluate the financial performance of the two major northern Indian banks.

Concerning their capital adequacy, asset quality, management capability, and liquidity, the financial performance of these two banks was found as sound and satisfactory by the study. (Roman \& Sargu, 2013) used the CAMELS framework to comparatively analyzes the financial soundness of the commercial banks of Romania.

The results from the study highlighted the strengths and the vulnerabilities of the analyzed banks and suggested guidelines to improve and increase their soundness. (Venkatesh \& Chithra, 20I4) used the CAMELS model to analyze the financial efficiency of selected commercial banks in the kingdom of Bahrain which is considered as the financial hub of the Middle East and plays a significant role in the economic activities in the Mena Region.

(Barker \& Holdsworth, 1993) mentioned in their study that in the prediction of banks' failure CAMEL rating is useful.

(Cole \& Gunther, 1998) conducted a study to assess the accuracy of CAMELS ratings in predicting the failure of banks. They used CAMELS as a benchmark and an off-site monitoring system based on publicly available accounting data.

(Nurazi \& Evans, 2005) also investigated whether CAMEL ratios could be used to predict bank failure. It has proven to be a useful internal supervisory tool for evaluating the soundness of a financial firm, based on identifying those institutions requiring special attention or concern.

(Yuksel, Dincer \& Hacioglu, 2015) exhibited the relationship between CAMELS ratios and credit ratings of twenty depository banks in Turkey. They used secondary data for the period (2004-20I4) and analyzed 2I different ratios of CAMELS components.

(Moudud-Ul-Huq, 2017) attempted to measure the financial performance of PCBs in Bangladesh. In the study, primarily he selected IO PCBs and collected data for the periods 20I3-20I4. For measuring the financial performance and rating these banks according to the composite rating system, CAMELS was employed by the study.

(Rahman \& Islam, 2018) in their study took an attempt to evaluate and compare the performance of the banking sector in Bangladesh. Accordingly, the CAMELS rating system had been employed by the study to grade the banks based on their performances.

\section{I Research Gap}

A review of previous pieces of the literature reveals that some studies have been done in the context of the performance of banks, benchmarking, and CAMELS components in different countries. From the perspective of Bangladesh, several research works have been conducted so far to make a comparative analysis of PCBs to examine the differential impact of various CAMEL components upon banks' profitability. Few articles and research papers explore the CAMEL rating of the commercial banks and few kinds of research explore the comparative analysis of the conventional and Islamic banks which are performing in Bangladesh. On the other hand, this study has conducted benchmarking to find the composite ratings of the selected banks to examine the performance of the banks based on CAMELS components. So, this study is different from the earlier studies in the sense that it highlights the composite rating approach using the CAMELS components. All the six components including "S", to 
assess the position of the banks in the market and create a space for the respective policymakers of the PCBs of Bangladesh to undertake initiatives to improve their bank's performance to attain a better rating.

\section{Methodology of the Study}

The present study has been carried out to assess the performance of the PCBs of Bangladesh. The population of the study is, therefore, all the PCBs that are enlisted in the Dhaka Stock Exchange (DSE) and Chittagong Stock Exchange (CSE). However, Sharia-based Islamic banks have been excluded from the study as their operating systems are not similar to conventional banks. Again, banks which have not adequate data available for the period of the study also have been excluded from the study. Finally, 2I PCBs have been selected for the study to evaluate their performance based on CAMELS components. Data has been collected from the financial statements and annual reports of respective banks for the period of 2008 to 20I8. Besides, the researcher visited the websites of DSE, CSE, Bangladesh Bank, and Bangladesh Securities and Exchange Commission to gather required data when necessary. The data has been analyzed and interpreted using tables and graphs. Analyses have been performed to assess the performance of the selected PCBs and identify the composite ratings of the selected PCBs based on CAMELS components. Six components of the CAMELS model (capital adequacy, asset quality, management efficiency, earnings ability, liquidity, and sensitivity to market risk) are used as variables.

\section{Overview of Benchmarking and Composite Rating of PCBs in Bangladesh}

To benchmark each component of CAMELS, they are to be evaluated on the scale of "I" to "5" rating in ascending order. Each component has a well thought out scale of rating based on the prevailing financial and economic conditions. Table 2 shows the details of the conversion of the CAMELS financial ratios to the progressive scale, which starts from "I" as strong to "5" as weak and for each equation used after relying on many previous studies to develop these ratios. Bangladesh Bank also follows the same formula and criteria whenever to examine the CAMELS rating for the banks.

Table 2. Benchmarking under the CAMELS Rating System

\begin{tabular}{|c|c|c|c|c|c|c|}
\hline \multirow[t]{2}{*}{ Code } & \multirow[t]{2}{*}{ CAMELS Component } & \multicolumn{5}{|c|}{ Ratio's Ranking } \\
\hline & & $\mathrm{I}$ & 2 & 3 & 4 & 5 \\
\hline $\mathrm{C}$ & Capital Adequacy (CRAR) & $>11 \%$ & $8-11 \%$ & $4-<8 \%$ & $\mathrm{I}-4 \%$ & $<\mathrm{I} \%$ \\
\hline $\mathrm{A}$ & $\begin{array}{l}\text { Asset Quality (NPL to } \\
\text { Total Loan Ratio) }\end{array}$ & $<1.5 \%$ & $1.5-3.5 \%$ & $3.5-7 \%$ & $7-9.5 \%$ & $>9.5 \%$ \\
\hline $\bar{M}$ & $\begin{array}{l}\text { Management Efficiency } \\
\text { (Operating Expense to } \\
\text { Operating Income Ratio) }\end{array}$ & $<25 \%$ & $26-30 \%$ & $3 \mathrm{I}-38 \%$ & $39-45 \%$ & $>46 \%$ \\
\hline$E$ & Earnings Ability (ROA) & $>1.5 \%$ & $\mathrm{I} .25-\mathrm{I} .5 \%$ & $\mathrm{I} .0 \mathrm{I}-\mathrm{I} .25 \%$ & $0.75-1.00 \%$ & $<0.75 \%$ \\
\hline $\mathrm{L}$ & Liquidity (ADR) & $<60 \%$ & $60-65 \%$ & $65-70 \%$ & $70-80 \%$ & $>80 \%$ \\
\hline $\bar{S}$ & Sensitivity $(\mathrm{P} / \mathrm{E})$ & $<\mathrm{I} 0 \%$ & I0-I5\% & I5\%-20\% & $20 \%-25 \%$ & $>25 \%$ \\
\hline $\begin{array}{l}\text { specifi } \\
\text { includ } \\
\text { bank a } \\
\text { to the }\end{array}$ & $\begin{array}{l}\text { Source: (Majithiya \& Pattan } \\
\text { Composite rating assigns on } \\
\text { the most robust performane } \\
\text { risk profile and the level of } \\
\text { indicates the most decisively } \\
\text { nk's size, complexity includin }\end{array}$ & $\begin{array}{l}\text { I0; Babar } \\
\text { umerical ss } \\
\text { f the bant } \\
\text { imum sup } \\
\text { cient level } \\
\text { sk profile. }\end{array}$ & $\begin{array}{l}\text { eb, } 201 \text { I; Sarw } \\
\text { 'I" to " } 5 \text { ", wh } \\
\text { d best manage } \\
\text { ory apprehensi } \\
\text { erformance of } \\
\text { the maximum }\end{array}$ & $\begin{array}{l}\text { Asif, 20II; Mr } \\
\text { "I" indicates th } \\
\text { practices relev } \\
\text { Whereas, rating } \\
\text { ank and insuffi } \\
1 \text { of supervisory }\end{array}$ & $\begin{array}{l}\text { yut \& Rahman, } \\
\text { ighest rating of } \\
\text { to the bank's } \\
\text { " shows the lov } \\
\text { t management } \\
\text { ncern. The foll }\end{array}$ & $\begin{array}{l}\text { 2) } \\
\text { bank, which } \\
\text { e, complexity } \\
\text { rating of the } \\
\text { ctices relevant } \\
\text { ng Table } 3 \text { is }\end{array}$ \\
\hline
\end{tabular}

Table 3. Composite Rating and its Interpretation

\begin{tabular}{cccl}
\hline Composite Rating & Range & Description & \multicolumn{1}{c}{ Rating Analysis Interpretation } \\
\hline I & I- I.4 & Strong & Strong and sound in every aspect, no intensive supervisory responses are required. \\
\hline 2 & I.5-2.4 & Satisfactory & Fundamentally sound with modest correctable weakness, limited supervisory response. \\
\hline 3 & $2.5-3.4$ & Fair & $\begin{array}{l}\text { A combination of weaknesses, if not redirected the weaknesses will become severe. Watch } \\
\text { category. Pre-requisites are more than regular supervision. }\end{array}$ \\
\hline
\end{tabular}




\begin{tabular}{|c|c|c|c|}
\hline 4 & $3.5-4.4$ & Marginal & $\begin{array}{l}\text { Excessive weaknesses, unless adequately addressed, could impair the future viability of the } \\
\text { bank. Requires close supervision. }\end{array}$ \\
\hline 5 & $4.5-5$ & Unsatisfactory & $\begin{array}{l}\text { High risk of failure in the immediate period. The bank should be under constant } \\
\text { supervision/cease and desist order. }\end{array}$ \\
\hline
\end{tabular}

The classification grades are usually divided into the six components of the mentioned standard according to the following weights for each system component or according to the monetary authority, as shown in Table 4.

Table 4. CAMELS Components' Weights

\begin{tabular}{ccccccc}
\hline Item & C & A & M & E & L & S \\
\hline Weight & $20 \%$ & $20 \%$ & $25 \%$ & $15 \%$ & $10 \%$ & $10 \%$ \\
\hline Source: & (Dirheb, 20 I0; & Shakara & $20 I 2 \%$ Ma & \\
\hline
\end{tabular}

Source: (Dirheb, 20I0; Shakara, 20I2; Masood, Ghauri, \& Aktan, 20I6)

\section{Data Analysis and Discussion}

\section{I Composite Range for CAMELS Rating}

In this composite study range of the selected PCBs using the CAMELS components has been calculated for the year 2008 to 2018. Table5 below provides the outcomes of CAMELS components of the selected PCBs along with their ratings. The value of each CAMELS component has been shown afterward in the figures separately. From Table 5 and the following Figures

(Figure I-6) rating of each selected bank based on CAMELS components can be comprehended easily.

Table 5. Outcomes of CAMELS Components of the PCBs (FY 2008-2018)

\begin{tabular}{|c|c|c|c|c|c|c|c|c|c|c|c|c|c|}
\hline Code & Banks & $\mathrm{C}$ & $\mathrm{R}$ & $\mathrm{A}$ & $\mathrm{R}$ & $\mathrm{M}$ & $\mathrm{R}$ & $E$ & $\mathrm{R}$ & $\mathrm{L}$ & $\mathrm{R}$ & $\mathrm{S}$ & $\mathrm{R}$ \\
\hline$B$ & Bank Asia & 12.16 & I & 3.94 & 3 & 39.04 & 4 & I.3I & 2 & 83.33 & 5 & 9.58 & I \\
\hline $\mathrm{D}$ & City & 12.63 & $\mathrm{I}$ & $5.8 \mathrm{I}$ & 3 & 49.14 & 5 & 1.34 & 2 & 80.52 & 5 & 13.37 & 2 \\
\hline$E$ & $\overline{\mathrm{DBBL}}$ & $\mathrm{I} 2.57$ & $\bar{I}$ & 3.63 & 3 & 56.29 & 5 & 1.36 & 2 & 76.52 & 4 & 17.67 & 3 \\
\hline $\mathrm{G}$ & EBL & $\mathrm{I} 2.53$ & I & 2.87 & 2 & 39.87 & 4 & I.74 & $\mathrm{I}$ & 88.13 & 5 & I2.07 & 2 \\
\hline $\mathrm{H}$ & IFIC & II.06 & $\mathrm{I}$ & 5.27 & 3 & $52.8 \mathrm{I}$ & 5 & I.I7 & 3 & 83.66 & 5 & I6.3I & 3 \\
\hline I & Jamuna & II.75 & $\mathrm{I}$ & 4.65 & 3 & 44.37 & 4 & 1.38 & 2 & 77.73 & 4 & 8.50 & $\mathrm{I}$ \\
\hline $\mathrm{J}$ & Mercantile & I I. 42 & $\mathrm{I}$ & $3.8 \mathrm{I}$ & 3 & 45.60 & 4 & $\mathrm{I} .2 \mathrm{I}$ & 2 & 83.15 & 5 & 8.59 & I \\
\hline $\mathrm{N}$ & Premier & II.43 & $\mathrm{I}$ & 5.09 & 3 & 57.34 & 5 & $\mathrm{I} .35$ & 2 & 84.37 & 5 & 8.66 & $\mathrm{I}$ \\
\hline $\mathrm{O}$ & Prime & 13.03 & $\mathrm{I}$ & 4.32 & 3 & 43.98 & 4 & $\mathrm{I} .25$ & 2 & 82.57 & 5 & $\mathrm{I} 2.57$ & 2 \\
\hline $\mathrm{P}$ & Pubali & II.90 & I & 5.34 & 3 & 26.70 & 2 & I.I5 & 3 & 83.48 & 5 & 14.04 & 2 \\
\hline$Q$ & SEBL & II.5I & $\mathrm{I}$ & 4.42 & 3 & 29.44 & 2 & $\mathrm{I} .25$ & 2 & 68.91 & 3 & 2.80 & $\mathrm{I}$ \\
\hline $\mathrm{R}$ & Standard & II.93 & I & $3.7 \mathrm{I}$ & 3 & 49.79 & 5 & 1.40 & 2 & 85.69 & 5 & 9.12 & $\mathrm{I}$ \\
\hline $\mathrm{S}$ & Trust & I2.39 & I & 3.45 & 3 & 49.04 & 5 & 0.98 & 4 & 82.02 & 5 & 7.64 & I \\
\hline $\mathrm{T}$ & UCBL & 10.70 & 2 & $4.5 \mathrm{I}$ & 3 & $45.5 \mathrm{I}$ & 4 & $\mathrm{I} .24$ & 3 & 80.42 & 5 & 10.98 & 2 \\
\hline $\mathrm{U}$ & Uttara & 12.28 & I & 6.22 & 3 & 51.60 & 5 & $\mathrm{I} .24$ & 3 & 67.11 & 3 & 9.99 & $\mathrm{I}$ \\
\hline
\end{tabular}

Source: Researcher's Calculation 
Whereas, $\mathrm{C}=$ Capital Adequacy (CRAR), $\mathrm{A}=$ Asset Quality (NPL to Total Loan Ratio), M = Management Efficiency (Operating Expense to Operating Income Ratio), $\mathrm{E}=$ Earnings Ability (ROA), L= Liquidity Ratio (Advance to Deposit Ratio), $\mathrm{S}=$ Price/Earnings Ratio, $\mathrm{R}=$ Rating.

\section{I.I Capital Adequacy}

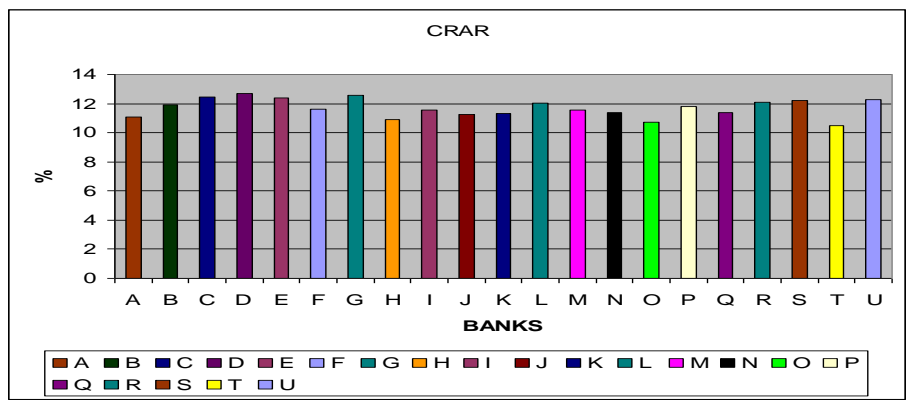

Figure I. Composite Rating of the Selected PCBs concerning CRAR

\section{I.2 Asset Quality}

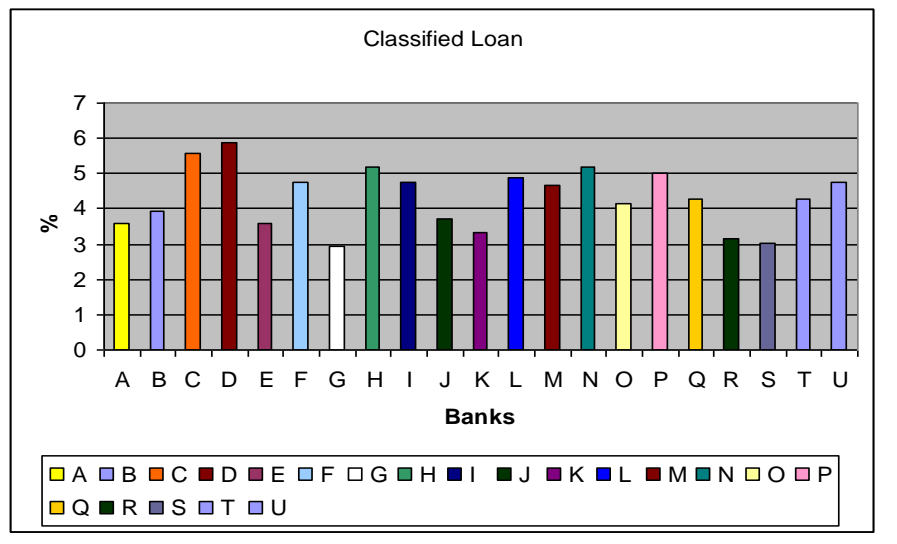

Figure 2. Composite Rating of the Selected PCBs concerning NPLs

\section{I.3 Management Efficiency}

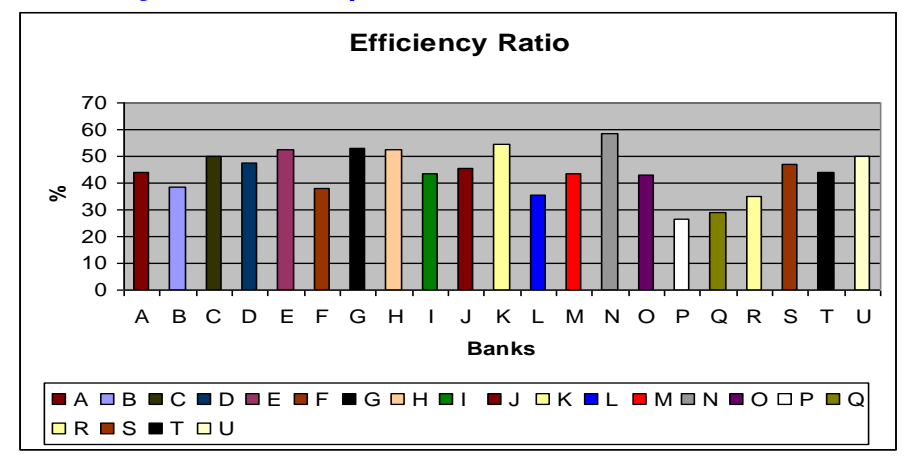

Figure I shows the composite ratings of the selected $\mathrm{PCBs}$ concerning CRAR. It is understandable from the figure and Table 5 that among the $2 \mathrm{I}$ banks most of the banks have the CRAR above II\%, and according to the CAMELS composite rating, most of the banks have reached the highest level. Only AB and UCBL have earned rating 2 with average CRAR below $11 \%$.
The most significant indication to show the asset quality in the loan assortment is the ratio of gross nonperforming loans (NPLs) to total loans. Figure 2 displays the composite ratings of the selected PCBs concerning asset quality for the year 2008 to 2018. From Table 5, it is observed that among the 2I PCBs, only EBL obtains 'satisfactory' rating. The rest 20 banks have been facing challenges with their classified loan. Because of the weak management of the loan portfolio and lack of diversification in their asset portfolio, most of the PCBs fail to generate sufficient financial returns. Moreover, these banks require maintaining higher provision as their NPL grows day by day. It creates pressure on banks' profitability too.

Management efficiency is an essential pre-requisite for the strength and growth of any bank. Figure 3 shows the efficiency ratio of PCBs from the year 2008-20I8. It is evident from Table5 that most of the banks perform poorly to show their management efficiency. Among the 2I sampled banks, IO banks get 5 (unsatisfactory) grading points, and 8 of them got 4 grading points. Unfortunately, no bank falls under the 'strong' position, and only Pubali and SEBL get 'satisfactory' ratings.

Figure 3. Composite Rating of the Selected PCBs concerning Expense-Income Ratio

Therefore, it is clear that the PCBs of Bangladesh are very inefficient in the management field. This weakness is represented by the management's inability to adjust the banking policy on sound bases. This also indicates that management has no plans to develop future banking policies as it has been observed during the last II years. 


\section{I.4 Earnings Ability}

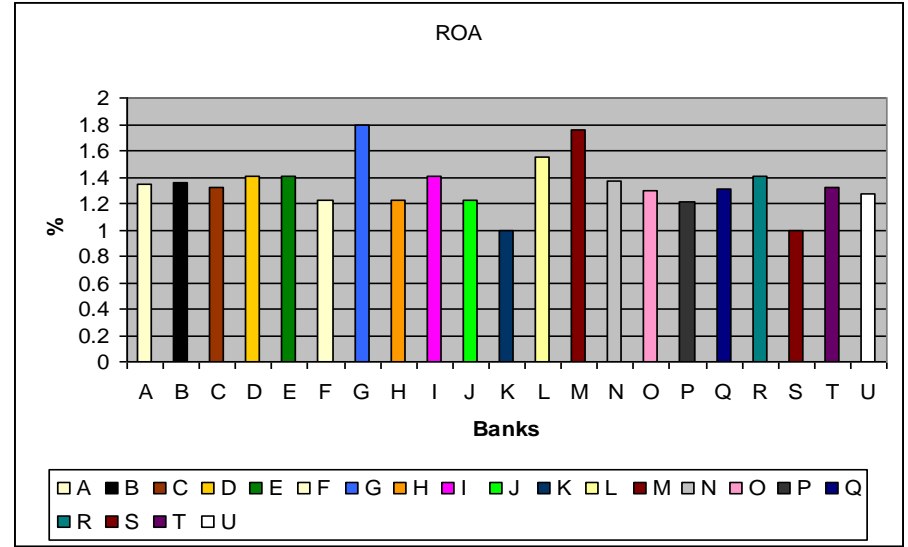

Figure 4. Composite Rating of the Selected PCBs concerning ROA

\section{I.5 Liquidity}

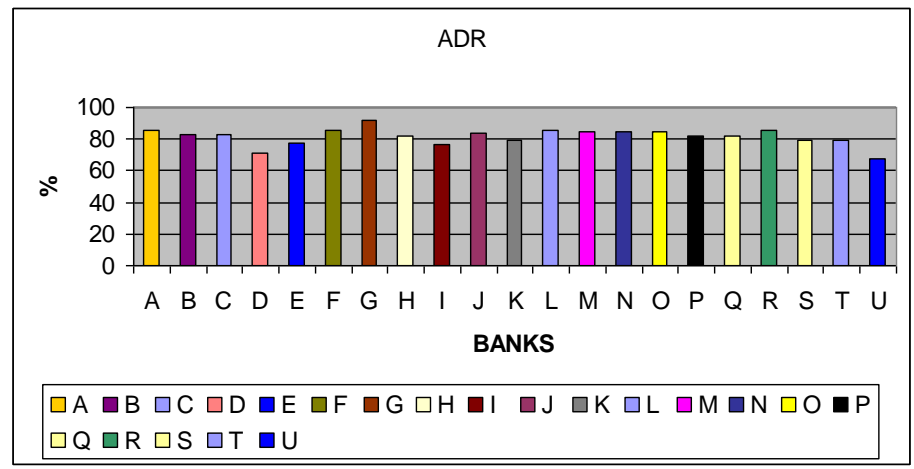

Figure 5. Composite Rating of the Selected PCBs concerning ADR

\subsubsection{Sensitivity}

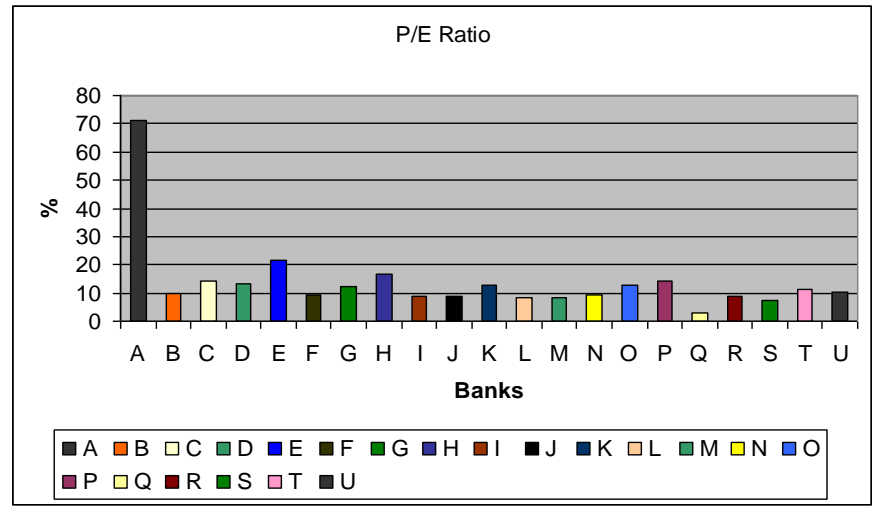

Figure 6. Composite Rating of the Selected PCBs concerning PE
Figure 4 is showing the ROA of the selected banks from 2008-20I8. Here it is observed from Table 5 that among 2I banks, the ROA of EBL is higher $(1.74 \%)$. ONE bank has also reached the highest level (I.65\%) of 'earnings' ratings. According to Table5, the performance of the other I8 banks is either 'satisfactory' or 'fair'. However, MTB and Trust bank show 'unsatisfactory' performance during the period of study. 'Earnings' achieved by these banks is not within the required level. This means that the banks incur high expenses and have doubtful debts, which also affected the decline in profits. And the banks need strong strategies to reduce costs.

Figure 5 is showing the advance to deposit ratio of the 2I banks for the year 2008-20I8. It is observed from Table5 that except SEBL and Uttara bank, most of the banks' ADR are alarmingly more than $80 \%$. It is meant that in terms of liquidity, the banks' performance is not 'satisfactory' or even 'fair'. Instead, their performance is 'unsatisfactory' and 'marginal'. The probable cause of most banks' sufferings from a lack of liquidity is due to their low realized profits, non-performing loans, and an increase in expenditures.

\section{I.7 Combined Rating}

After depicting the CAMELS components in the previous figures, the study has reached at the final stage now. Table 6shows the final score for each selected bank.

It is seen from Table 5 that the PE ratio of SEBL shows very 'strong'. Performances of most other selected banks are between $7 \%$ and $17 \%$ except $\mathrm{AB}$. Unfortunately, the $\mathrm{PE}$ of $\mathrm{AB}$ bank is very 'unsatisfactory'. Figure 6 shown beside expresses the PE ratios of the selected banks. If the PE ratio of any bank is too high, then investors assume the stocks as overvalued and that doesn't express a strong rating of the bank. So from the analyst, the PE ratio between $05-15 \%$ is better, which may express 'strong', 'satisfactory', or 'fair' performance of the banks. In this study, concerning $\mathrm{PE}$ ratio of most of the banks has a fair/satisfactory/strong rating except $A B$ bank. The Higher $\mathrm{PE}$ ratio of the banks expresses the overvaluation of their stocks. 
Table 6. Combined Rating of CAMELS Components of PCBs with Weights (FY 2008-2018)

\begin{tabular}{|c|c|c|c|c|c|c|c|c|}
\hline Banks & $C(20 \%)$ & $\mathrm{A}(20 \%)$ & $\begin{array}{c}M \\
(25 \%)\end{array}$ & $\mathrm{E}(\mathrm{I} 5 \%)$ & L (I0\%) & $S(10 \%)$ & CR & Position \\
\hline AB Bank & 2 & 3 & 4 & 3 & I & 5 & 3.5 & Marginal \\
\hline Bank Asia & I & 3 & 4 & 2 & I & I & 2.7 & Fair \\
\hline BRAC & I & 3 & 5 & 2 & I & 2 & 3.1 & Fair \\
\hline City & I & 3 & 5 & 2 & I & 2 & 3.1 & Fair \\
\hline DBBL & I & 3 & 5 & 2 & 2 & 3 & 3.1 & Fair \\
\hline Dhaka & I & 3 & 3 & 3 & I & I & 2.6 & Fair \\
\hline EBL & I & 2 & 4 & I & I & 2 & 2.5 & Fair \\
\hline IFIC & I & 3 & 5 & 3 & I & 3 & 3.3 & Fair \\
\hline Jamuna & I & 3 & 4 & 2 & 2 & I & 2.6 & Fair \\
\hline Mercantile & I & 3 & 4 & 2 & I & I & 2.7 & Fair \\
\hline MTB & I & 3 & 5 & 4 & I & 2 & 3.4 & Fair \\
\hline $\mathrm{NCC}$ & I & 3 & 5 & 2 & I & I & 3.0 & Fair \\
\hline ONE & I & 3 & 4 & I & I & I & 2.6 & Fair \\
\hline Premier & I & 3 & 5 & 2 & I & I & 3.0 & Fair \\
\hline Prime & I & 3 & 4 & 2 & I & 2 & 2.8 & Fair \\
\hline Pubali & I & 3 & 2 & 3 & I & 2 & 2.5 & Fair \\
\hline SEBL & I & 3 & 2 & 2 & 3 & I & 2.0 & Satisfactory \\
\hline Standard & I & 3 & 5 & 2 & I & I & 3.0 & Fair \\
\hline Trust & I & 3 & 5 & 4 & I & I & 3.3 & Fair \\
\hline UCBL & 2 & 3 & 4 & 3 & I & 2 & 3.2 & Fair \\
\hline Uttara & I & 3 & 5 & 3 & 3 & I & 2.9 & Fair \\
\hline
\end{tabular}

Source: Researcher's Calculation

Where, $\mathrm{C}=$ Capital Adequacy (CRAR), A = Asset Quality (NPL to Total Loan Ratio), M = Management Efficiency (Operating Expense to Operating Income Ratio), $\mathrm{E}=$ Earnings Ability (ROA), L= Liquidity Ratio (Advance to Deposit Ratio), $\mathrm{S}=$ Price/Earnings Ratio, $\mathrm{CR}=$ Composite Rating.

From Table- 6, it is found that out of $2 \mathrm{I}$ banks, none of the sample banks can achieve the 'strong' position and only one bank (SEBL) can secure a 'satisfactory' mark. Most of the sampled banks (I9 in numbers) have achieved a 'fair' position that is $90 \%$ of the whole sample. Therefore, these banks need to be controlled and followed-up and develop considerable cost reduction programs. Unfortunately, AB bank narrowly slips from 'fair' position and becomes rated "marginal" in their composite rating that is the lowest rating among the sample banks. Therefore, $A B$ is at risk and may lead to failure. The bank needs to develop reform and follow-up programs as soon as possible to avoid financial failure. Also, it needs to review the types of provided loans.

\section{Conclusion}

The banking sector is playing a major role to materialize most of the transactions happening throughout the world. Performance appraisal and overall evaluation help both banks and their stakeholders to assess the outcomes of the bank's policies and operations in monetary terms. Since PCBs have dominated the whole financial sector of Bangladesh, therefore, it was essential to assess banks' ratings in the market and evaluate the performance for both banks and its stakeholders to assess the outcomes of every bank's policies and operations. In this study, the CAMELS rating system was employed through the benchmarking approach on 2I sampled PCBs of Bangladesh. Through the value of a composite rating for each selected bank, the position of these banks has been realized. It is seen that most of the PCBs have sufficient capital adequacy. The earning 
performance of these banks is more or less worthy. Their PE ratio is also sensible. But the banks have been facing challenges with their classified loan. The management efficiency of these banks is very modest. And in terms of liquidity, the banks' performance is not satisfactory as well.

Therefore, the policymakers of the related lowest ranking banks have to carry out the required steps to overcome their weaknesses and get better their performance. And it is expected that the outcomes of this research work would be useful for administrators of the selected PCBs in Bangladesh to recover their monetary crises and develop strategies that would improve their operational performance and banking activities as well.

\section{I Limitations of the Study and Scope for Further Research}

The study is not liberal from limitations. It is mainly based on secondary data, so a lack of adequate and necessary data might affect the research. Even because of different constraints with social patterns in Bangladesh, it was felt unable to collect information about the PCBs of Bangladesh, mostly when annual data of each bank were not available digitally. Therefore, all the PCBs were not included in the study. Again, the banks which are not listed in the capital markets of Bangladesh, i.e., DSE or CSE, were excluded from this study. The study has used only one ratio for evaluating the CAMELS. PE ratio was used to measure the sensitivity to market risk. In the future, therefore, a study with a much larger sample of commercial banks in Bangladesh with the inclusion of all CAMELS components may give a better representation. For more research, the study can add some samples by adding a time series or total bank samples. More ratios could be incorporated to signify each component of CAMELS.

\section{References}

Anderson, K. \& McAdam, R. (2006). A critique of benchmarking and performance management. Lead or Lag. Benchmarking: An International Journal, II(5), 465-483. Retrieved from https://www.researchgate.net/publication/238325847_A_critique_of_benchmarking_and_performance_measurem ent_Lead_or_lag

Annual Report of Bangladesh Bank (2018-19). Retrieved from https://bb.org.bd/pub/annual/anreport/arI8I9/indexI8I9.php

Babar, H. Z., \& Zeb, G. (20II). Camels rating system for the banking industry in Pakistan: does the CAMELS system provide a similar rating as PACRA system in assessing the performance of banks in Pakistan? (Master's Thesis). Umea School of Business, Sweden. Retrieved from https://www.semanticscholar.org/paper/Camels-rating-system-for-bankingindustry-in-\%3A-does-Babar-Zeb/I I97fa888fI6b438bfef8I3e78I I e8c595bfba8b

Barker, D. \& Holdsworth, D. (1993). The causes of bank failures in the 1980s. Federal Reserve Bank of New York, Research Paper No. 9325. Retrieved from https://ideas.repec.org/p/fip/fednrp/9325.html

Barr, R. S., Killgo, K. A., Siems, T. F., \& Zimmel, S. (2002). Evaluating the productive efficiency and performance of US commercial banks. Managerial Finance, 28(8), 3-25. Retrieved from https://www.emerald.com/insight/content/doi/I0.I 108/03074350210767988/full/html

Cole, R. A., \& Gunther, J. (1998). Predicting Bank Failures: A Comparison of On-And Off-Site Monitoring Systems. Journal of Financial Services Research, I3(2), pp. I03-I I7.https://link.springer.com/article/I0.1023/A:I0079547I8966

Credit Rating Agency of Bangladesh Ltd. (2020). Retrieved from www.crab.com.bd

Dirheb, M. S. (2010). Bank Risk Assessment System (CAMELS). Iraqi Journal of Administrative Sciences, II(I5), $260-300$.

Knights, D. \& McCabe, D. (2006). A bridge too far? Consistent quality initiatives in financial services. The TQM Magazine, $8(5), 5 \mathrm{I}-55$.

Moudud-Ul-Huq, S. (2017). Performance of banking industry in Bangladesh: Insights of CAMEL rating. International Journal of Financial Engineering, 4(02n03), 1750006.

Majithiya, R \& Pattani, A. (2010). Rating the performance of the bank through CAMELS model. Post Diploma thesis, Tolani Institute of Management Studies, India.

Masngut, M., \& Rahman, A. (2012). Financial distressed: detection model for Islamic banks. Business and Social Science Research Conference. Paris.

Masood, O., Ghauri, S. M. K., \& Aktan, B. (2016). Predicting Islamic banks performance through CAMELS rating model. Banks and Bank Systems, II(3), 37-43. Retrieved from https://www.semanticscholar.org/paper/Predicting-Islamicbanks-performance-through-CAMELS-Masood-Ghauri/db5e9ebc85f64If623c3fdb562Ic547707062bf7

Nurazi, R., \& Evans, M. (2005). An Indonesian study of the use of camel(s) ratios as predictors of bank failure. Journal of Economic and Social Policy, IO(I), $6 . \quad$ Retrieved from https://www.researchgate.net/publication/37357823_An_Indonesian_Study_of_the_Use_of_CAMELS_Ratios_a s_Predictors_of_Bank_Failure 
Raju, B. H. (2017). Cost and Profit Efficiency of Bangladeshi Commercial Banks: A Stochastic Frontier Approach. International Joumal of Economic Behavior and Organization, 5(6), I3I-I42. https://doi.org/I0.2139/I0.I I648/j.ijebo.20170506.I3

Rahman, Z., \& Islam, S. (2018). Use of camel rating framework: a comparative performance evaluation of selected Bangladeshi private commercial banks. International Journal of Economics and Finance, IO(I). Retrieved from http://www.ccsenet.org/journal/index.php/ijef/article/view/7I545

Roman, A., \& Şargu, A. C. (2013). Analyzing the financial soundness of the commercial banks in Romania: An approach based on the camels framework. Procedia Economics and Finance, 6, 703-712. Retrieved from https://www.sciencedirect.com/science/article/pii/S22I2567I I300I925

Sahajwala, R., \& Van den Bergh, P. (2000). Supervisory Risk Assessment and Early Warning Systems. Basel Committee on Banking Supervision Working Papers, No. 4, Bank of International Settlements. Retrieved from https://www.researchgate.net/publication/472455I_Supervisory_risk_assessment_and_early_warning_systems

Sangmi, M., \& Nazir, T. (2010). Analyzing financial performance of commercial banks in India: application of camel model. Pakistan Joumal of Commerce and Social Sciences, 4(I), 40-55. Retrieved from https://www.econstor.eu/handle/I04I9/I87999

Sarwar, A., \& Asif, S. (20I I). Safety and soundness of financial sector of Pakistan: CAMEL rating application. Interdisciplinary Journal of Contemporary Research in Business, 3(2), 624-630.

Shakara, M. A. B. (2012). Assess the performance of banks under CAMELS standards. Journal of Accounting and Financial Studies, 7(18), I34-I54.

Suba, N. (2015). Financial performance analysis of selected public and private sector banks: a study through camel model. A Ph.D. Thesis in the Department of Commerce, Saurasthtra University, India.

Tzu, S. (2002). Translated by John Minford. The Art of War. Viking. Retrieved from https://www.jstor.org/stable/40244134

Venkatesh, D., \& Suresh, C. (20I4). Comparative Performance Evaluation of Selected Commercial Banks in Kingdom of Bahrain Using CAMELS Method. Available at SSRN 24I8I44. https://doi.org/I0.2139/ssrn.24I8I44.

Yuksel, S., Dincer, H., \& Hacioglu, U. (20I5). CAMELS-based Determinants for the Credit Rating of Turkish Deposit Banks. International Journal of Finance \& Banking Studies, 4(4), I.Retrived from https://www.ssbfnet.com/ojs/index.php/ijfbs/article/view/363

\section{Copyrights}

Copyright for this article is retained by the author(s), with first publication rights granted to the journal. This is an open-access article distributed under the terms and conditions of the Creative Commons Attribution license (http://creativecommons.org/licenses/by/4.0/). 